đưa bênh nhân đi khám để chẩn đoán, phát hiện và điều trị sớm các yếu tố thúc đẩy.

Nghiên cứu của chúng tôi ghi nhận càng nhiêu yếu tố thúc đẩy, bệnh não gan càng nặng. Do đó, số lượng các yếu tố thúc đẩy có mối liên quan đến mức độ bệnh não gan $(p=0,0001)$. Nghiên cứu của Muntaz, kết quả cho thấy số lượng từ hai yếu tố thúc đẩy trở lên có môi liên quan đến mức độ bênh não gan $(p=0,025)$, và những bệnh nhân có từ hai yếu tố thúc đẩy trở lên sẽ có bệnh não gan độ III hoặc độ IV lúc nhập viện [6]. Tương tự với nghiên cứu của Lê Hà Xuân Sơn [5], kết quả cũng tìm thây mỗi liên quan giữa số lượng yếu tố thúc đẩy và mức độ bệnh não gan $(p=0,019)$.

\section{KẾT LUÂN}

Yếu tố nhiễm trùng và hạ natri máu có mối liên quan với bệnh não gan và mức độ nặng của bệnh lý. Nghiên cứu cho thấy có sự liên quan giữa số lượng yếu tố thúc đẩy với mức độ bệnh não gan, do vậy phòng ngừa cũng như tầm soát các yếu tố thúc đẩy là cần thiết để hạn chế diễn tiến của bệnh não gan lâm sàng.

\section{TÀI LIỆU THAM KHẢO}

1. Agrawal S, Umapathy S, Dhiman RK. Minimal Hepatic Encephalopathy Impairs Quality of Life. Journal of Clinical and Experimental Hepatology. 2015; 5:42-48.

2. Quero Guillen JC, Herrerias Gutierrez JM. Diagnostic methods in hepatic encephalopathy. Clinica Chimica Acta. 2006; 365: 1-8.

3. Jepsen $P$, Ott $P$, Andersen $\mathbf{P K}$, Soresen $\mathbf{H T}$, Vilstrup $\boldsymbol{H}$. The clinical course of alcoholic liver cirrhosis: a Danish population-based cohort study. Hepatology. 2010; 51: 1675-1682.

4. Sharma BC, Sharma $P$, Agrawal A, Sarin SK Secondary prophylaxis of hepatic encephalopathy: an open-label randomized controlled trial of lactulose versus placebo. Gastroenterology. 2009; 137: 885-891.

5. Lê Hà Xuân Sơn. Khảo sát mối tương quan giữa các yếu tố thúc đẩy và tử vong trên bênh nhân Bệnh não gan loại C. Luận văn tốt nghiệp bác sĩ nội trú, Đại học Y khoa Pham Ngoc Thach. 2015. tr. 1-70.

6. Mumtaz K, Ahmed US, Abid S, Baig N, Hamid $\mathbf{S}$, Jafri W. Precipitating Factors and The Outcome of Hepatic Encephalopathy in Liver Cirrhosis. Journal of the College of Physicians and Surgeons Pakistan. 2010; 20(8):514-518.

7. Shawcross DL, Davies NA, Williams R, Jalan R. Systemic inflammatory response exacerbates the neuropsychological effects of induced hyperammonemia in cirrhosis. Journal of Hepatology. 2004; 40(2):247-254.

8. Atluri DK, Prakash R, Mullen KD. Pathogenesis, diagnosis, and treatment of hepatic encephalopathy. Journal of Clinical and Experimental Hepatology. 2011; 1(2): 77-86.

\title{
KHẢO SÁT VÀ ĐÁNH GIÁ VIÊCC SỬ DỤNG KHÁNG SINH VANCOMYCIN TẠI BỆNH VIỆN ĐA KHOA ĐỒNG NAI
}

\section{TÓM TẮT}

Kháng vancomycin đã làm dấy lên mối lo ngại về triển vọng hiệu quả trong điều trị bệnh nhân nhiếm khuẩn Gram dương. Nghiên cứu được thực hiện tại bệnh viên đa khoa Đồng Nai từ tháng 3/2019 đến tháng 6/2019. Phương pháp: Nghiên cứu hồi cứu để đánh giá việc kê đơn và sử dụng vancomycin tại bệnh viện. Kết quả được xác định và biểu thị bằng các liệu trình vancomycin trên 98 bệnh nhân nhập viện. Thông tin về bệnh nhân được thu thập bao gồm: nhân khẩu học, căn nguyên và vị trí của nhiễm trùng, dữ liệu vi sinh, chế độ liều lượng, cách dùng và thời gian điều trị, độc tính trên thận của vancomycin. Kết quả: Tuổi trung bình và thời gian điều trị vancomycin lần lượt là 56 tuổi và 9 ngày. Nhiễm trùng da mô mêm (44\%) là nguyên nhân phổ biến nhất. Can thiệp y tế chủ yếu là

${ }^{1}$ Đại học Lạc Hồng, Đồng Nai

Chịu trách nhiệm chính: Đinh Thị Thúy Hà

Email: Dinhthuyha85@gmail.com

Ngày nhận bài: 18.01.2021

Ngày phản biên khoa họ: 16.3 .2021

Ngày duyệt bài: 23.3.2021
Đinh Thị Thúy Hà ${ }^{1}$

thở máy $(28,6 \%)$. Số lượng bệnh nhân có kết quả khỏi, đỡ, giảm chiếm tỉ lệ cao $(66,3 \%)$. Chế độ liều nạp được áp dụng ở 13,3 \% bệnh nhân với liêu nạp thễo cẩn nặng $25,6 \mathrm{mg} / \mathrm{kg}$. Đa số bệnh nhân trong mẫu nghiên cứu dùng chế độ liều ban đầu $1 \mathrm{~g} / 12$ giờ (78,6\%) khi chức năng thận bình thường. $100 \%$ bênh nhân được sử dụng đường truyền tĩnh mạch ngắt quảng, 96,9\% trường hợp có dung môi pha truyền hợp lý, $100 \%$ phù hợp về thời gian truyền và $63,2 \%$ phù hợp về nồng độ truyền. 7 bệnh nhân có sự thay đổi creatinine huyết thanh (tăng $>50 \%$ so với giá trị ban đâu), đều xuất hiện ít nhất sau 7 ngày, muộn nhất sau 14 ngày sử dụng vancomycin. Kết luận: Cần có các chương trình toàn diện để cải thiện việc sử dung vancomycin trong các bệnh viên. Việc sử dụng Vancomycin nên được theo dõi để tổi ưu hóa việc sử dụng thuốc.

Tư khóa: vancomycin, sử dụng thuốc

\section{SUMMARY \\ EVALUATION OF VANCOMYCIN USE AT DONG NAI GENERAL HOSPITAL}

Objectives: Vancomycin resistance has raised concerns about outcome prospects in the treatment of 
Gram-positive infections. The study was conducted at Dong Nai General Hospital from March 2019 to June 2019. Methods: retrospective study to evaluate the prescription and use of vancomycin in hospital. Results were determined and documented in 98 hospitalized patients. Information on patients was collected including: demographic, etiology and location of infection, microbiological data, dosage regimen, administration and renal toxicity of vancomycin. Results: The mean age of the patient and vancomycin treatment duration were 56 years and 9 days, respectively. Soft tissue and skin infections (44\%) is main cause when using vancomycin. The main medical intervention is ventilator (28.6\%). The number of patients with cured, better and reduced symtom is high $(66.3 \%)$. The loading dose was applied in $13.3 \%$ of patients with a dose of $25.6 \mathrm{mg} / \mathrm{kg}$. The majority of patient in the research used the initial dose of $1 \mathrm{~g} / 12$ hour $(78.6 \%)$ with normal renal fuction. $100 \%$ patient using intermittent IV infusion, $100 \%$ suitable for administration time and $63.2 \%$ suitable for infusion concentration. There were 7 patients with changes in serum creatinine (increase> 50\% compared with baseline value), occurring at least after $7-14$ days of using vancomycin. Conclude: An entire program is needed to improve vancomycin use in hospitals. Vancomycin use should be monitored to optimize its use.

Keywords: vancomycin, drug use, drug utilization.

\section{I. ĐặT VẤN ĐỀ}

Vi khuẩn đề kháng kháng sinh được coi là "mối đe dọa cơ bản" đối với sức khỏe toàn cầu. Vancomycin là kháng sinh glycopeptide được sử dụng ở giai đoạn đầu của liệu pháp điều trị MRSA. Việc sử dụng vancomycin không đúng cách làm tăng nguy cơ xuất hiện các bệnh nhiễm trùng do vi khuẩn đa kháng thuốc, giảm hiệu quả điều trị, gia tăng thời gian nằm viện và chi phí điều trị. Sự xuất hiện nhanh chóng của các vi khuẩn đa kháng thuốc như Methicillin Resistant Staphylococcus Aureus (MRSA) và Enterococci kháng vancomycin (VRE) được coi là một vấn đề nan giải trong thực hành y tế [4]. Các điều chỉnh hiện tại nhằm đạt mục tiêu nồng độ huyết thanh của vancomycin trên nồng độ ức chế tối thiểu (MIC). Để đạt được mục tiêu này liều lượng và nồng độ đáy vancomycin cao là cần thiết. Liều lượng dựa trên cân nặng được khuyến cáo để đạt được các mục tiêu mới này [8]. Nhằm khảo sát đặc điểm sử dụng vancomycin giúp tăng cường việc sử dụng kháng sinh an toàn, hợp lý chúng tôi tiến hành đề tài: "Khảo sát và đánh giá việc sử dụng vancomycin trong trị liệu tại bênh viện đa khoa Đồng Nai" với những mục tiêu sau: (1)Khảo sát đặc điểm sử dụng vancomycin trong điều trị và so sánh với liều khuyến cáo của Hiệp hội dược sĩ Mỹ (AphA); (2) Khảo sát và so sánh hiêuu quả điều tri và biến cô bất lợi trên thận của việc sử dụng vancomycin.

\section{II. ĐỐI TƯợNG VÀ PHƯƠNG PHÁP NGHIÊN CứU}

Đối tượng nghiên cứu: Hồ sơ bệnh án của bệnh nhân được chỉ định vancomycin tại bệnh viện đa khoa Đồng Nai.

Tiêu chuấn chọn mẫu: Tất cả bệnh nhân $>18$ tuổi được chỉ định vancomycin trong thời gian nghiên cứu.

Tiêuu chuẩn loại trừ: Thời gian sử dụng vancomycin dưới 3 ngày, bệnh nhân dưới 18 tuổi, bệnh nhân không có chẩn đoán nhiếm khuẩn, bệnh nhân có thay đổi về dược động học (phụ nữ có thai, bệnh nhân có tiển hành lọc máu, bênh nhân bị mất dịch ngoại bào như bỏng, nồn nhiêu, tiêuu chảy nặng, bệnh nhân bị xơ nang, phù hay cổ trướng).

Phương pháp nghiên cứu: Nghiên cứu cắt ngang mô tả, thời gian nghiên cứu từ tháng 03/2019 đến tháng 06/2019. Thông tin về nhân khẩu học, đặc điểm nhiễm khuẩn, kết quả xét nghiệm (creatinine huyết thanh, xét nghiệm nuôi cấy vi khuẩn/ độ nhạy), thuốc sử dụng (chỉ định, đường dùng, chế độ liều, thời gian điều trị), hiệu quả điều trị dựa trển đáp ứng lâm sàng và thời gian nằm viện, độc tính trên thận được thu thập từ hồ sơ bệnh án. Trong đó:

Đặc điểm nhiễm khuẩn bao gồm: nhiễm khuẩn phức tạp (nhiễm khuẩn huyết/ sốc nhiễm khuẩn huyết, viêm phổi, viêm màng não, viêm nội tâm mạc, viêm tủy xương/ viêm xương khớp), nhiễm khuẩn nhẹ: (nhiễm khuẩn da - mô mềm, nhiễm khuẩn ổ bụng, nhiễm khuẩn tiết niệu).

Đô loc cầu thân (GFR) đã được tính toán cho tất cả bệnh nhân sử dụng công thức CockroftGualt như một ước tính độ thanh thải creatinin. Phân loại mức độ nghiêm trọng của độc tính trên thận theo tiêu chí creatinin của RIFLE bảng 1

Bảng 1. Phân loại mức độ độc tính trên thận theo tiêu chí creatinine của RIFLE

\begin{tabular}{|c|c|}
\hline Mức độ & Tiêu chí xác định \\
\hline R - nguy co & $\begin{array}{l}\text { Tăng nông độ creatinin trên 1,5 } \\
\text { lần hoặc GFR giảm > 25\% }\end{array}$ \\
\hline I - tổn thương & $\begin{array}{c}\text { Tăng nồng độ creatinin trên } 2 \text { lần } \\
\text { hoặc GFR giảm > } 50 \%\end{array}$ \\
\hline F - suy & $\begin{array}{c}\text { Tăng nồng độ creatinin trên } 3 \text { lân } \\
\text { hoặc GFR giảm > }>5 \%\end{array}$ \\
\hline $\begin{array}{l}\text { L - mất chức } \\
\text { năng }\end{array}$ & $\begin{array}{l}\text { Suy thận cấp dai dăng=mất chức } \\
\text { năng thận hoàn toàn }>4 \text { tuần }\end{array}$ \\
\hline $\begin{array}{l}\text { E - bệnh thận } \\
\text { giai đọan cuối }\end{array}$ & $\mathrm{g}$ \\
\hline
\end{tabular}

Liều dùng của vancomycin được so sánh với liều khuyến cáo dựa trên GFR được tính toán trong các hướng dẫn của hội Dược sĩ Hoa Kỳ (APhA) chuyên khảo vancomycin (Bảng 2). Liều lượng chênh lệch hơn $20 \%$ được coi là liều lượng không chính xác. 
Bảng 2. Liều khuyến cáo vancomycin cho người lớn $\mathrm{CrCl}$ (mL/phút)

(tính theo

Cockcroft Gault)

\section{Cân nặng thực}

\begin{tabular}{|c|c|c|c|c|c|c|}
\hline \multicolumn{7}{|c|}{ Nhiềm trùng nghiêm trọng/mô sâu: nồng độ đáy mục tiều $15-20 \mu \mathrm{g} / \mathrm{ml}$} \\
\hline$<10$ (không & \multicolumn{6}{|c|}{ Lặp lại liêu khi đo nồng độ đáy bất kỳ $\leq 20 \mu \mathrm{g} / \mathrm{ml}$} \\
\hline $\begin{array}{l}10 \text { - } 19 \text { (không } \\
\text { thẩm phân máu) }\end{array}$ & $750 \mathrm{~m}$ & 1000 & 100 & Bh & $48 \mathrm{~h}$ & 15( \\
\hline $20-29$ & $500 m$ & 750 & $\mathrm{~h}$ & ih & 1250 & $1250 \mathrm{n}$ \\
\hline $30-39$ & $750 \mathrm{~m}$ & 750 & & 12 & 125 & \\
\hline $40-49$ & & 750 & & & $118 \mathrm{~h}$ & 1120 \\
\hline & & 100 & & & 125 & 150 \\
\hline & & & & & & \\
\hline & & & & & & \\
\hline & & & & & 150 & \\
\hline 99 & 100 & 100 & & 150 & 150 & \\
\hline$\geq 100$ và $<60$ tuối & $750 \mathrm{mg} / 8 \mathrm{~h}$ & $750 \mathrm{mg} / 8 \mathrm{~h}$ & $1000 \mathrm{mg} / 8 \mathrm{~h}$ & $1250 \mathrm{mg} / 8 \mathrm{~h}$ & $1250 \mathrm{mg} / 8 \mathrm{~h}$ & $1250 \mathrm{mg} / 8 \mathrm{~h}$ \\
\hline
\end{tabular}

Phân tích số liệu:Thống kê mô tả được thực hiện và dữ liệu được phân tích bằng cách sử dụng phép thử chi bình phương hoặc phép thử chính xác của Fisher để so sánh hai tỷ lệ. Phép kiểm t-test (nếu phân phối chuẩn) hoặc Wilcoxon Rank Sum test (nếu phân phối không chuẩn) được áp dụng để so sánh hai số trung bình. SPSS Statistics phiên bản 20.0 được sử dụng để phân tích các khác biệt đáng kể. Dữ liệu được trình bày dưới dạng giá trị trung bình và SD. Giá trị $P \leq 0,05$ được coi là có ý nghĩa thống kê.

\section{KẾT QUẢ NGHIÊN CỨU}

Trong thời gian 5 tháng có tổng số 98 bệnh nhân được đưa vào nghiên cứu (61 nam và 37 nữ), được dùng vancomycin. 20 bệnh nhân bị loại trừ do thiếu thông tin. Tuổi và cân nặng trung bình của bệnh nhân là 56,7 tuổi (khoảng $16-89, \mathrm{SD}=16,07$ ) và $54,05 \mathrm{~kg}$ (khoảng $30-105$, $\mathrm{SD}=16,83$ ) tương ứng. Những lý do chính sử dụng vancomycin là nhiễm trùng da mô mềm $(44,9 \%)$ và viêm phổi $(34,7 \%)$. Trong mẫu nghiên cứu các nhiễm khuẩn như viêm phổi, viêm màng não, nhiễm khuẩn huyết chiếm tỷ lệ cao trong phân nhóm nhiễm khuẩn nặng và nhiễm trùng da - mô mềm chiếm tỷ lệ cao trong phân nhóm nhiễm khuẩn nhẹ. Trung vị thời gian nằm viện là 19 ngày.

Bảng 3. Đặc điểm bệnh nhân trong mẫu nghiên cứu

\begin{tabular}{|c|c|c|}
\hline Đặc điểm & $\begin{array}{c}\text { Tân suất } \\
(\mathbf{n}=\mathbf{9 8})\end{array}$ & Tỉ lệ \\
\hline Tuối, TB \pm ĐLCa & $56,7 \pm 16,07$ & \\
\hline Giới, $\mathrm{n}(\%)$ & & \\
\hline
\end{tabular}

\begin{tabular}{|c|c|c|}
\hline Nam & 61 & 62,2 \\
\hline Nữ & 37 & 37,8 \\
\hline Cân nặng, TB \pm ĐLCa & $58,3 \pm 12,5$ & \\
\hline BMI, TB \pm ĐLCa & $22,8 \pm 4,5$ & \\
\hline \multicolumn{3}{|l|}{ Bệnh kèm } \\
\hline Đái tháo đường & 43 & 43,9 \\
\hline Tim mạch & 40 & 40,8 \\
\hline $\begin{array}{c}\text { Bệnh thâan (suy thận, hội } \\
\text { chứng thận hư') }\end{array}$ & 21 & 21,4 \\
\hline \multicolumn{3}{|l|}{ Can thiệp y tế } \\
\hline Thơ máy & 28 & 28,6 \\
\hline Sonde tiếu & 19 & 19,4 \\
\hline Cắt lọc da, cơ, cân, ghép da & 18 & 18,4 \\
\hline \multicolumn{3}{|l|}{ Loại nhiếm trùng } \\
\hline Da, mô mềm & 44 & 44,9 \\
\hline Viêm phổi & 34 & 34,7 \\
\hline Xương khớp & 7 & 7,1 \\
\hline $\begin{array}{l}\text { Thời gian nằm viên (trung } \\
\text { vi, khoảng tứ phân vị) }\end{array}$ & $19(13-29)$ & \\
\hline \multicolumn{3}{|l|}{ Chức năng thận ban đầu } \\
\hline Creatinin máu $(\mathrm{mg} / \mathrm{dL})$ & $0,75 \pm 0,36$ & \\
\hline $\mathrm{CrCl}$ (mL/phút) & $75,4 \pm 18,1$ & \\
\hline $\mathrm{CrCl} \leq 60 \mathrm{~mL} /$ phút & 24 & 24,5 \\
\hline \multicolumn{3}{|l|}{ Thay đối cận lâm sàng khác } \\
\hline Tăng Bạch cầu & 67 & 68,4 \\
\hline Tăng CRP & 47 & 47,9 \\
\hline Tăng Procalcitonin & 21 & 21,4 \\
\hline Tăng ure máu & 30 & 30,6 \\
\hline $\begin{array}{l}\text { Kết quả điêuu trị } \\
\text { Khỏi } \\
\text { Đỡ } \\
\text { Không thay đổi } \\
\text { Nặng hơn }\end{array}$ & $\begin{array}{c}6 \\
59 \\
16 \\
13 \\
\end{array}$ & $\begin{array}{l}6,1 \\
60,2 \\
16,3 \\
13,2 \\
\end{array}$ \\
\hline
\end{tabular}

TB: trung bình, DLC: độ lệch chuẩn 


\section{Đặc điểm sử dụng vancomycin trong mẫu nghiên cứu}

Liều dùng vancomycin. Chúng tôi đã so sánh liều lượng với khuyến cáo liều quy đinh dựa trên hai phương pháp tiêu chuẩn hóa khác nhau (khuyến cáo APhA và hướng dẫn liều dùng vancomycin theo cân nặng khuyến cáo cho người lớn) đối với vancomycin điêu chỉnh liều theo GFR của bệnh nhân. Dữ liệu được hiển thị trong bảng 4.

Bảng 4. Đặc điểm liều dùng vancomycin

\begin{tabular}{|c|c|c|}
\hline Đặc điểm & $\begin{array}{l}\text { Tân suất } \\
(\mathrm{n}=98)\end{array}$ & Tỉ lệ \\
\hline $\begin{array}{l}\text { Thời gian dùng (trung vi, } \\
\text { khoảng tứ phân vị) }\end{array}$ & $9(6,0-13,0)$ & \\
\hline \multicolumn{3}{|l|}{ Liều nạp } \\
\hline $\begin{array}{l}\text { Tổng liều nạp } 1500 \\
\text { Tổng liều nạp } 1000 \\
\text { Liều nạp theo cân nặng }\end{array}$ & $\begin{array}{c}3 \\
10 \\
25,6(22,6-29,2)\end{array}$ & $\begin{array}{c}3,1 \\
10,2\end{array}$ \\
\hline Liều duy trì (mg) & & \\
\hline $1000, \mathrm{q} 12 \mathrm{~h}$ & 77 & 78,6 \\
\hline $1000, \mathrm{q} 24 \mathrm{~h}$ & 9 & 9,2 \\
\hline $500, \mathrm{q} 12 \mathrm{~h}$ & 7 & 7,1 \\
\hline $\begin{array}{c}500, \mathrm{q} 24 \mathrm{~h} / 1000, \mathrm{q} 48 \mathrm{~h} / \\
1000, \mathrm{q} 8 \mathrm{~h} / 500, \mathrm{q} 8 \mathrm{~h}\end{array}$ & 8 & 8,2 \\
\hline $500, q 48 \mathrm{~h} / 1500, \mathrm{q} 24 \mathrm{~h}$ & 2 & 2,0 \\
\hline
\end{tabular}

Chế độ liều duy trì của bệnh nhân trong mấu nghiên cứu tương ứng nhiều mức liều khác nhau. Các mức liêu duy trì vancomycin (theo gam) trên hệ số thanh thải creatinin (Clcr) được thể hiện trong hình 1:

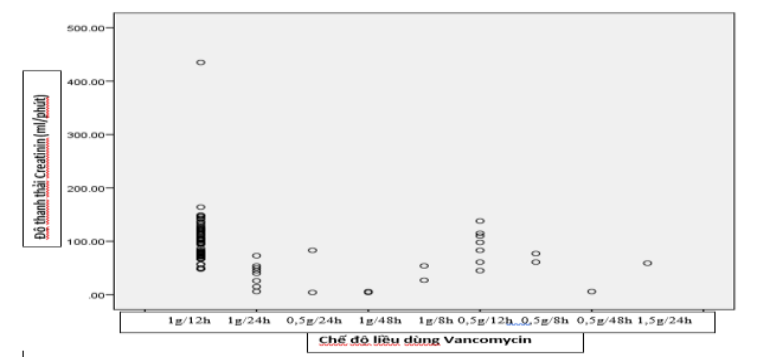

Hình 1. Liều duy trì vancomycin

Bảng 5. Đường dùng và cách dùng vancomycin

\begin{tabular}{|c|c|c|c|}
\hline \multicolumn{2}{|c|}{ Tiêu chí đánh giá } & \multirow{2}{*}{$\begin{array}{c}\begin{array}{c}\text { Tân } \\
\text { suất }\end{array} \\
98\end{array}$} & \multirow{2}{*}{$\begin{array}{c}\begin{array}{c}\text { Tỉ } \\
\text { lệ }\end{array} \\
100\end{array}$} \\
\hline Đương dùng & $\begin{array}{l}\text { Truyền tĩnh } \\
\text { mạch }\end{array}$ & & \\
\hline $\begin{array}{l}\text { Dung môi pha } \\
\text { truyền }\end{array}$ & $\begin{array}{l}\text { Natri clorid } \\
\text { Nước cất }\end{array}$ & $\begin{array}{l}95 \\
03\end{array}$ & $\begin{array}{c}96,9 \\
3,1\end{array}$ \\
\hline \multirow{2}{*}{$\begin{array}{l}\text { Nồng độ sau khi } \\
\text { pha loãng }(\mathrm{mg} / \mathrm{ml})\end{array}$} & $\leq 5$ & 62 & 63,2 \\
\hline & 10 & 29 & 29,6 \\
\hline \multirow{3}{*}{$\begin{array}{l}\text { Thời gian truyên } \\
\text { vancomycin } \\
\text { (phút) }\end{array}$} & $<60$ & 0 & 0 \\
\hline & & 35 & 35,7 \\
\hline & $91-120$ & 63 & 64,3 \\
\hline
\end{tabular}

Toàn bộ trường hợp được chỉ định vancomycin đều sử dụng đường truyền tînh mạch ngắt quãng. Dung môi dùng pha truyền chủ yếu là natri clorid $0,9 \%(96,9 \%)$. Nồng đô dung dịch pha truyền được ghi nhận phần lớn là $\leq 5 \mathrm{mg} / \mathrm{ml}$. Khảo sát thời gian truyên, chúng tôi nhận thấy không có trường hợp nào thời gian truyền <60 phút, có $64,3 \%$ trường hợp có thời gian truyền $>90$ phút.

Độc tính trên thận. Tỷ lệ bệnh nhân được ghi nhận có độc tính trên thận và mức độ độc tính trên thân được trình bày trong bảng 6 . Tỷ lệ phát sinh độc tính trên thận thấp khoảng $7 \%$, trong đó nguy cơ tổn thương thận do tăng 1,5 lần creatinine là chủ yếu $(4,1 \%)$.

Bảng 6. Đặc điểm trên thận và kêt quả điều tri của $B N$

\begin{tabular}{|c|c|c|}
\hline & $\begin{array}{l}\text { Tân } \\
\text { suất }\end{array}$ & Tỉ lệ \\
\hline $\begin{array}{l}\text { Tỷ lệ phát sinh độc tính trên thận, } \\
\text { n (\%) Mức độ độc tính trên thận }\end{array}$ & 7 & $7,1 \%$ \\
\hline $\begin{array}{l}\mathrm{R} \text { (Tăng nồng độ creatinin trên } 1,5 \\
\text { lần-nguy cơ) }\end{array}$ & 4 & $4,1 \%$ \\
\hline $\begin{array}{l}\text { I (Tăng nồng độ creatinin trên } 2 \\
\text { lần-tổn thương) }\end{array}$ & 1 & $1,1 \%$ \\
\hline $\begin{array}{l}\text { F (Tăng nồng độ creatinin trên } 3 \\
\text { lần-suy) }\end{array}$ & 2 & $2,1 \%$ \\
\hline $\begin{array}{l}\mathrm{L} \text { (Suy thận cấp dai dằng = mất } \\
\text { chức năng thận hoàn toàn > } 4 \text { tuần) }\end{array}$ & 0 & $0,0 \%$ \\
\hline E (ESRD > 3 tháng) & 0 & 0,0 \\
\hline
\end{tabular}

\section{BÀN LUÂ̂N}

Đặc điểm bệnh nhân. Trung vị độ tuổi bênh nhân trong mẫu nghiên cứu là 56 tuổi và giới tính nam chiếm đa số $(62,2 \%)$. Bệnh nhân thường mắc nhiều bệnh kèm, trong đó chủ yếu các bệnh lý tim mach và đái tháo đường $(83 \%)$. Can thiêp y tế chủ yếu là thở máy $(28,6 \%)$. Đặc điểm nhiễm trùng chủ yếu là nhiễm trùng da mô mềm chiếm tỉ lệ 44\%. Trong nghiên cứu của chúng tôi thời gian nằm viện tương đối dài trung vị 19 ngày. Qua thời gian điều trị, số lượng bệnh nhân có kết quả khỏi, đõ̃, giảm chiếm tỉ lệ cao nhất $(66,3 \%)$. Khảo sát chức năng thận ban đầu có 24,5\% bệnh nhân có suy giảm chức năng thận.

\section{Đặc điểm sử dụng vancomycin}

Chế độ liều dùng và thời gian dùng. Sử dụng vancomycin cần dựa trên chủng vi khuẩn, mức độ nghiêm trọng của nhiễm trùng, cân nặng của bệnh nhân và chức năng thân. Theo khuyến cáo của hội nhiễm khuẩn Hoa Kỳ̀, đối với bệnh nhân nhiễm trùng mô sâu (nhiếm trùng máu, viêm nội tâm mạc, viêm tủy xương, nhiễm trùng do thay khớp giả, viêm phổi phải nhập viện, nhiễm trùng liên quan đến hệ thần kinh 
trung ương và/hoặc bệnh nặng): khởi đầu bằng liều nạp $25-30 \mathrm{mg} / \mathrm{kg}$, tối đa $3 \mathrm{~g} /$ liều (làm tròn trong khoảng $250 \mathrm{mg}$ ). Dùng 1 liều duy nhất, 12 giờ sau sử dụng liều duy trì $15-20 \mathrm{mg} / \mathrm{kg}$, tối đa $2 \mathrm{~g} /$ /iều mỗi 12 giờ để đạt được nồng độ đáy mục tiêu $15-20 \mathrm{mcg} / \mathrm{ml}[7],[8]$.

Chế độ liều nạp được áp dụng ở 13,3 \% bệnh nhân với liều nạp theo cân nặng $25,6 \mathrm{mg} / \mathrm{kg}$. Kết quả tương đồng với nghiên cứu của Nguyển Thị Mai Anh (21\% bệnh nhân, dao động 20$40 \mathrm{mg} / \mathrm{kg}$ ) [3]. Trong những năm gần đây chế độ liều nạp của vancomycin đối với các bệnh nặng (nhiễm khuẩn huyết, viêm màng nã̃o, viêm phổi...) được đề cập trong các hướng dẩn điều trị. Việc dùng liều cao Vancomycin có thể xuất hiện tác dụng không mong muốn (hội chứng người đỏ) nên xem xét tăng thời gian tiêm truyền thuốc 90-120 phút và sử dụng thuốc kháng histamin trước khi dùng liều nạp. Như vậy một lượng nhỏ bệnh nhân trong mẫu nghiên cứu bị bỏ qua chế độ liều nạp, điều này cũng hợp lý do hầu hết các trường hợp trong nghiên cứu là nhiễm khuẩn da mô mêm không nghiêm trọng để áp dụng chế độ liều nạp.

Đa số bệnh nhân trong mẫu nghiên cứu dùng chế độ liều ban đầu $1 \mathrm{~g}$ và khoảng cách liều mổi 12 giờ $(78,6 \%)$ khi chức năng thận bình thường. Tỉ lệ này cao hơn nhiều so với nghiên cứu của Bùi Thị Hương Quỳnh và Triệu Alpha $(52,48 \%)$ [1]. Chế độ liều $1 \mathrm{~g}$ mỗi 24 giờ hoặc $500 \mathrm{mg}$ mỗi 12 giờ thường được sử dụng khi có suy giảm chức năng thận $(16,3 \%)$. Kết quả khác biêtt với nghiên cứu của Nguyễn Thị Mai Anh (1g mối $12 \mathrm{~h}$ (29\%) và $1 \mathrm{~g}$ mỗi $24 \mathrm{~h}(67 \%)$. Có 2 bệnh nhân được sử dụng chế độ liều $500 \mathrm{mg}$ mối 8 giờ để đạt được nồng độ đáy mục tiêu do bệnh nhân trẻ tuổi và chức nẳng thận bình thường. Mức liều $1 \mathrm{~g} / 12$ giờ hay $15 \mathrm{mg} / \mathrm{kg} / 12$ giờ thường được áp dụng khi giá trị MIC $<1 \mathrm{mg} / \mathrm{L}$ để đạt chỉ số $\mathrm{PK} / \mathrm{PD}$ mục tiêu. Với $\mathrm{MIC}=1 \mathrm{mg} / \mathrm{L}$ và mức liêuu $3 \mathrm{~g} /$ ngày, tỉ lệ đạt $\mathrm{PK} / \mathrm{PD}$ mục tiêu là $80 \%$, nguy cơ độc tính trên thận là 25\% [6]. Qua kết quả khảo sát giá trị MIC của vancomycin với tụ cầu vàng tại bênh viên đa khoa Đồng Nai năm 2018, có $100 \%$ giá trị MIC $\leq 1 \mathrm{mg} / \mathrm{L}$. Như vậy mức liều $1 \mathrm{~g} / 12$ giờ vancomycin có thể phù hợp với số lượng lớn bệnh nhân. Theo hướng dẫn điều trị MRSA của hiệp hội nhiễm khuẩn Hoa Kỳ, mức liều duy trì của vancomycin là $15-20 \mathrm{mg} / \mathrm{kg}$ mỗi 8-12 giờ, không quá $2 \mathrm{~g}$ mỗi lần. Viêc giám sát nồng độ đáy nên áp dụng với bệnh nhân béo phì, suy giảm chức năng thận và có thay đổi thể tích phân bố do nguy cơ tích lũy liều [8]. Đối với bệnh nhân có hệ số thanh thải từ $10-50 \mathrm{ml} /$ phút không có can thiệp lọc máu, mức liều vancomycin phổ biến là $1 \mathrm{~g} / 24$ giờ $(15 \mathrm{mg} / \mathrm{kg} / 24$ giờ). Kết quả khảo sát có 6 trường hợp có chức năng thân suy giảm sử dung mức liều quá cao (1g/8 giờ) và ngược lại 5 trường hợp chức năng thận bình thường sử dụng mức liều thấp $(0,5 \mathrm{~g} / 12 \mathrm{giờ}, 0,5 \mathrm{~g} / 24 \mathrm{giờ})$.

Thời gian sử dụng vancomycin trung vi là 9 ngày, dao động từ 2 - 26 ngày. Kết quả tương đồng nghiên cứu của Đặng Nguyễn Đoan Trang (11 ngày, dao động 3-50 ngày) và nghiên cứu của Nguyễn Thị Mai Anh là 12 ngày [2],[3]. Vancomycin được chỉ định trong nhiều loại nhiễm khuẩn khác nhau nên thời gian điều trị khác nhau. Đối với viêm phổi mắc phải tại bệnh viện thời gian điều trị kháng sinh 7-14 ngày, tuy nhiên có thể rút ngẳn thời gian này nếu bênh nhân có cải thiện trên lâm sàng và xét nghiệm vi sinh.

Cách dùng vancomycin. Khảo sát về đường dùng vancomycin có $100 \%$ bênh nhân được sử dụng đường truyền tĩnh mach ngắt quảng. Nhiều nghiên cứu cho thấy rằng tiêm truyền liên tục Vancomycin không chứng minh cải thiện kêt quả điều trị trên bệnh nhân so với tiêm truyền ngắt quãng. Tuy nhiên, tiêm truyền liên tục có thể liên quan đến việc giảm hội chứng người đỏ và độc tính thận, mặc dù cần có thêm các thử nghiệm lâm sàng trước khi phương pháp này được sử dụng thường xuyên.

Đồng thời cách dùng vancomycin ảnh hưởng nhiều đến nguy cơ tác dụng không mong muốn. Truyền vancomycin với nồng độ cao $>5 \mathrm{mg} / \mathrm{ml}$ và tốc độ nhanh $>10 \mathrm{mg} /$ phút làm tăng nguy cơ xuất hiện phản ứng giả dị ứng. Vancomycin được khuyến cáo pha loãng bằng dung môi natriclorid $0,9 \%$ hoặc nước cất trước khi dùng với nồng độ trong khoảng 2,5-5mg/ml. Kết quả khảo sát tại bệnh viện Đồng Nai dung môi pha truyền có $100 \%$ trường hợp hợp lý, 100\% phù hợp về thời gian truyền.Tỉ lệ phù hợp về nồng độ truyền ở mức trung bình $63,2 \%$. Kết quả tương đồng với nghiên cứu của Nguyễn Thị Mai Anh và Bùi Hương Quỳnh.

Độc tính trên thận. Trong nghiên cứu của chúng tôi việc đánh giá tổn thương thận cấp được áp dụng theo tiêu chuẩn RIFLE. Có 7 bệnh nhẩn có sự thay đổi creatinine huyết thanh (tẳng $>50 \%$ so với giá trị ban đầu), đều xuất hiện ít nhất sau 7 ngày, muộn nhất sau 14 ngày sử dụng vancomycin. Trong đó 41,5\% bệnh nhân phối hợp thuốc có độc tính trên thận. Các nghiên cứu chỉ ra rằng nồng độ đáy $>20 \mathrm{mg} / \mathrm{L}$, thời gian sử dụng vancomycin trên 7 ngày và phối hợp các thuốc độc tính trên thận là yếu tố nguy cơ gây 
suy giảm chức năng thận [5]. Độc tính trên thận được báo cáo dao động từ $5-11 \%$ nếu sử dụng đơn độc và tăng lên đến $22 \%$ nếu phối hợp kháng sinh aminoglycoside và độc tính trên thận có thể xảy ra ở ngày điều trị thứ 5.

\section{KẾT LUẬN}

Cân có các chương trình toàn diện để cải thiện việc sử dụng vancomycin trong các bệnh viện. Việc sử dụng Vancomycin nên được theo dõi để tối ưu hóa việc sử dụng thuốc.

\section{TÀI LIÊU THAM KHẢO}

1. Bùi Thi Hương Quỳnh và Triệu Alpha (2018), "Khảo sát tình hình sử dụng vancomycin tại bệnh viện Thống Nhất thành phố Hồ Chí Minh", Tạp chí Y hoc, 1, 66-70.

2. Đặng Nguyễn Đoan Trang (2019), "Khảo sát và đánh giá hiêuu quả theo dôi nông đô vancomycin trong trị liêu tai Bênh viên Đai học Y̛ Dược thành phố hồ chí minh", Nghiến cứu dược và thông tin thuốc 2019, tập 10, số 3, trang 30-37

3. Nguyê̂n Thị Mai Anh (2019), "Phân tích thực trạng sử dụng kháng sinh vancomycin tại bệnh viện Thanh Nhàn", luân văn Thạc sĩ dược học, trường Đại học Y Hà Nội

4. Hiramatsu $\dot{k}$. Vancomycin-resistant Staphylococcus aureus: a new model of antibiotic resistance. Lancet Infect Dis 2001;1(3):147-55.

5. Linden P. K. (2007), "Optimizing therapy for vancomycin-resistant enterococci (VRE)", Semin Respir Crit Care Med. 28 (6), pp. 632-645.

6. Nimish Patel, Manjunath P. Pai, Keith A Rodvold, Ben Lomaestro, George L. Drusano, Thomas P. Lodise, Vancomycin: We Can't Get There From Here, Clinical Infectious Diseases, Volume 52 , Issue 8,15

7. Richard H Drew, George Sakoulas. Vancomycin: Parenteral dosing, monitoring and adverse effects in adults. Uptodate. Truy câp ngày 31/07/2017.

8. Rybak M, Lomaestro B, Rotschafer JC, et al. Therapeutic monitoring of vancomycin in adult patients: a consensus review of the American Society of Health-System Pharmacists, the Infectious Diseases Society of America, and the Society of Infectious Diseases Pharmacists. Am J Health Syst Pharm 2009; 66(1): 82-98.

\title{
KIẾN THỨC, THỰC HÀNH VỀ VÊ SINH AN TOÀN THỰC PHẨM CỦA NGƯỜI CHẾ BIẾN THỰC PHẨM TAI BẾP ĂN TẬP THỂ MộT Số BỆNH VIỆn TẠI HÀ NộI NĂM 2020
}

\author{
Nguyễn Thị Thu Hà ${ }^{1}$, Trịnh Bảo Ngọc ${ }^{1}$, Trần Ngọc Tụ ${ }^{2}$
}

\section{TÓM TẮT}

Một nghiên cứu cắt ngang được tiến hành trên 96 người chể biến thực phẩm tại bếp ăn tập thể của 32 bệnh viện tại Hà Nội. Kết quả của nghiên cứu này cho thấy tỷ lệ người chế biến thực phẩm có kiến thức chung về an toàn thực phẩm đạt 10,4\%. Tỷ lệ người chế biến thực phẩm có thực hành chung về an toàn vệ sinh thực phẩm (ATVSTP) đạt 55,2\%. Như vậy, tỷ lệ người chế biến thực phẩm có kiến thức và thực hành đạt về ATVSTP còn thấp.

Từ khóa: Vệ sinh thực phẩm, An toàn thực phẩm, bếp ăn tập thể, bệnh viện.

\section{SUMMARY \\ KNOWLEDGE, PRACTICES OF FOOD SAFETY AND HYGIENE OF FOOD HANDLERS AT THE COMMUNAL KITCHENS OF HOPITALS IN HA NOI IN 2020}

A cross-sectional study was conducted on 96 food processors in the communal kitchens of 32 hospitals in

\footnotetext{
${ }^{1}$ Viện Đào tạo YHDP \& YTCC, Đại học Y Hà Nội

${ }^{2}$ Chi cục An toàn vệ sinh thực phẩm Hà Nội

Chịu trách nhiệm chính: Nguyễn Thị Thu Hà

Email: hanguyen1595@gmail.com

Ngày nhân bài: 12.01.2021

Ngày phản biên khoa học: 16.3.2021

Ngày duyệt bài: 25.3.2021
}

$\mathrm{Ha}$ Noi. The results of this study showed that the proportion of food workers with general knowledge about food safety reached $10.4 \%$. The proportion of correct common food safety and hygiene practices of people personally dealing with food was $55.2 \%$. Thus, the proportion of food handlers who have both knowledge and practice about food safety is low.

Keywords; food hygiene, food safety, communal kitchen, hospital.

\section{I. ĐặT VẤN ĐỀ}

Ngộ độc thực phẩm là vấn đề sức khỏe cộng đồng phổ biến và quan trọng trên toàn thế giới. Tổ chức Y tế Thế giới (WHO) ước tính có tới $30 \%$ dân số mắc các bệnh do thực phẩm gây ra ở các nước phát triển và gây ra 2 triệu ca tử vong mỗi năm ở các nước đang phát triển[1].

Tại Việt Nam, theo số liệu của Tổng cục Thống kê cho thấy, năm 2017 ghi nhận 111 vụ ngộ độc thực phẩm, làm 3374 người bị ngộ độc và có 22 người đã bị tử vong. Trong 6 tháng đầu năm 2018, cả nước xảy ra 44 vụ ngộ độc thực phẩm, làm 1.207 người bị ngộ độc và 7 trường hợp tử vong[2].

Trong đó, bếp ăn tập thể (BĂTT) là nơi có nguy cơ cao dẫn đến ngộ độc thực phẩm (90\%) do số lượng suất ăn lớn nên quá trình chế biến 